\title{
Carbon Emission Trading Policy and Carbon Emission Efficiency: An Empirical Analysis of China's Prefecture-Level Cities
}

\author{
Lei Chen, Yining Liu, Yue Gao and Jingjing Wang* \\ Chongqingfuling Electric Power Industrial Co., Ltd., Chongqing, China
}

Improving carbon emission efficiency is an important means to achieve pollution reduction and sustainable economic development. Rather than focusing on the implementation of market-incentive environmental policies in developed countries, we study the effect of the implementation of market-incentive environmental policies on the efficiency of carbon

OPEN ACCESS

Edited by:

Xin Yao,

Xiamen University, China

Reviewed by:

Jianghua Liu,

Shanghai University of Finance and

Economics, China

Chang Liu,

Southwestern University of Finance and Economics, China

Aijun $\mathrm{Li}$,

Shandong University, China

${ }^{*}$ Correspondence: Jingjing Wang

jjwang_work@126.com

Specialty section:

This article was submitted to

Sustainable Energy Systems and

Policies,

a section of the journal

Frontiers in Energy Research

Received: 12 October 2021

Accepted: 18 November 2021

Published: 10 December 2021

Citation:

Chen L, Liu Y, Gao Y and Wang J (2021) Carbon Emission Trading Policy and Carbon Emission Efficiency: An Empirical Analysis of China's

Prefecture-Level Cities.

Front. Energy Res. 9:793601. doi: 10.3389/fenrg.2021.793601 emissions in developing countries, which is generally ignored by frontiers researches. Based on panel data of 282 cities at prefecture-level and above in China from 2007 to 2017, we first adopt the non-radial distance function (NDDF) and global DEA model to measure the carbon emission efficiency of China's cities. Then we take the Chinese carbon emission trading pilot as a quasi-natural experiment and explore the impact of carbon emission trading policy on carbon emission efficiency based on DID method. And the mechanisms are analyzed through the mediation effect model. It is found that the carbon emission rights trading policy can significantly improve the carbon emission efficiency of the pilot cities, and it mainly plays a role through three channels: technological progress effect, green innovation effect and energy consumption structure optimization effect. The heterogeneity test results show that for resource-based cities and cities with a higher degree of marketization, the carbon emission trading policy has a more obvious effect on improving carbon emission efficiency.

Keywords: carbon emission trading policy, carbon emission efficiency, technological progress, green innovation, energy consumption structure

\section{INTRODUCTION}

China's economy has achieved rapid growth in the past four decades based on the traditional factordriven development mode, which is accompanied by serious environmental pollution and high carbon emissions. In 2013, China's carbon emissions surpassed the European Union and the United States, making it the world's largest energy consumer and carbon emitter country. As the international community pays more attention to global climate change, China is under increasing pressure to reduce carbon emissions. China has proposed goal of carbon peak in 2030 and carbon neutralization in 2060, which puts forward higher requirements for carbon emission efficiency. To control carbon emissions as soon as possible, the Chinese government at all levels have carried out a series of environmental regulation policies to promote the carbon emissions over the years, such as developing low-carbon pilot cities and increasing forest carbon sinks. Carbon emission trading is also one of the key policies. Along with the advancement of market-based reform, the National 
Development and Reform Commission issued the Notice on The Pilot Work of Carbon Emission Trading in 2011. Seven provinces and cities, including Beijing, Tianjin, Shanghai, Chongqing, Hubei, Guangdong and Shenzhen, were selected as pilot cities for carbon emission trading, and all of them started online trading in 2014. This means that China has embarked on a market-oriented environmental policy and make use of the market mechanism to promote the improvement of carbon emission efficiency and achieve green and low-carbon development. The main approach of carbon emission trading is that government agencies estimate the maximum carbon emissions that meet the environmental capacity in a certain region and divide them into several emission shares. The government sells the emission right to carbon emission enterprises in the primary market for compensation, and the carbon emission enterprises can buy and sell the carbon emission right purchased in the secondary market. This paper aims to answer the following questions: whether market-oriented carbon trading policies can effectively improve carbon emission efficiency and achieve low-carbon development, and what are the ways and conditions for improving carbon emission efficiency?

However, the existing literature mainly focuses on the energy conservation and emission reduction effects of command-andcontrol environmental policies (Blackman and Kildegaard, 2010; Qin et al., 2016; Cheng et al., 2017; Zheng and Shi, 2017; Li and Masui, 2019). There are also some literatures on the effect of market-incentive environmental policies. Different from the command-and-control environmental policy, market-incentive environmental policy is an environmental regulation means based on market transactions such as energy trading and carbon emission trading rather than administrative regulation. However, due to the first implementation of carbon emission trading policies in developed countries with relatively perfect market trading mechanism and rich practical experience, such as Europe and the United States, the research objects of relevant literatures are mainly targeted at these developed countries (Brännlund et al., 1998; Chapple et al., 2013; Clarkson et al., 2015; Brouwers et al., 2016; Pearse, 2016; Schafer, 2019). And the researches on China's carbon emission trading are mainly based on the provincial level or enterprise level to investigate its emission reduction effect (Shen et al., 2020; Xuan et al., 2020; Li and Wang, 2021; Zhang et al., 2021) or economic effects, such as employment effect (Yang et al., 2020), economic growth effect (Li et al., 2019; Wu and Gong, 2021), the effect of technological innovation (Chen et al., 2020b; Song et al., 2021; Xiao et al., 2021), which lack of analysis on the impact of carbon emission trading on carbon emission efficiency from the level of prefecture-level cities in China. Based on this, the marginal contribution of this paper are as follows: Firstly, we calculated the carbon emission efficiency at the city level based on the balance panel data of 282 cities in China from 2007 to 2017. Secondly, based on the quasinatural experiment of carbon emission trading pilot project, we investigate the specific impact of market-oriented environmental policy on carbon emission efficiency using DID method, and analyze its impact mechanism and conditions. It is helpful to put forward effective suggestions for China and other developing countries to build a carbon emission trading market on a national scale.

\section{THEORETICAL HYPOTHESES \\ Direct Effect of Carbon Emissions Trading Policy on Carbon Emission Performance}

At present, there are two views on the impact of environmental regulations on pollution reduction among existing literatures. The first view is that environmental regulation damages the economic interests of enterprises by generating pollution control costs and is not conducive to the improvement of carbon emission efficiency (Blackman and Kildegaard, 2010; Tu and Chen, 2015; Zheng and Shi, 2017). The second one is based on the "Porter Hypothesis", which believes that environmental regulation can force enterprises to carry out innovative activities, improve their productivity to produce innovation compensation effect (Poter and Vanderlinde, 1995), eliminate backward production capacity, optimize resource allocation, and thus improve carbon emission efficiency. Du et al. (2021) verified that green technological innovation and industrial structure upgrading are two effective channels through which environmental regulation facilitate the economy's green transformation. Enterprises with high pollution control costs and backward production are pushed out of the market because their innovation compensation effect is smaller than the cost effect of pollution control (Xiao et al., 2021), which helps to improve the overall production efficiency of the society, promote the progress effect of green technology (Dong and Wang, 2019), and achieve emission reduction targets. Song et al. (2020) showed that with the increase of environmental regulation, its role in the promotion of green product innovation has gradually emerged. There are also studies showing that command-and-control environmental policies support the first view, while market-oriented environmental policies mainly produce innovation compensation effect (Tang et al., 2020). As a market-oriented environmental policy, carbon emission trading policy allocates carbon emissions as a kind of property right to each enterprise based on Coase (1960), and solves the negative externalities of environmental pollution and improves the efficiency of environmental control by trading emission rights in the market. From the perspective of enterprises, when the trading price of carbon emission right in the market is higher than the marginal cost of enterprise pollution control, enterprises would take the initiative to improve the efficiency of carbon emission based on the goal of profit maximization. At the same time, enterprises can effectively use the carbon emission quota to prevent additional carbon emission cost and sell the excess carbon emission quota by increasing the emission reduction to obtain additional income (Shakil et al., 2019). Based on this, this paper proposes the first theoretical hypothesis:

Hypothesis 1. Carbon emission trading policy can effectively improve the carbon emission efficiency of pilot cities. 


\section{Mediation Effect of Carbon Emissions Trading Policy on Carbon Emission Performance}

We expect that carbon emission trading policies may affect carbon emission efficiency through three intermediary channels. Firstly, carbon emission trading can affect carbon emission efficiency by changing the technological level and the direction of technological progress in cities. Since carbon emission trading policy limits the carbon emissions of enterprises, it increases the pressure on enterprises to reduce pollution. Faced with the pressure of emission reduction constrained by carbon emission quotas, enterprises mainly achieve emission reduction targets in two ways: one is to reduce output (Caparrós et al., 2013), and the other is to adopt new technologies and carry out green technological innovation to achieve cleaner production. However, the first approach is the most negative response adopted by enterprises to achieve emission reduction targets, which will not only damage their own interests, but also fail to reflect the practical significance of energy conservation and emission reduction. Instead, technological progress, especially green technological innovation, can effectively improve productivity and energy efficiency and reduce carbon emissions, which is an effective way to achieve energy conservation and emission reduction in the long run (Xuan et al., 2020; Cheng and Yao, 2021). On the one hand, enterprises can realize the surplus of carbon quota through their own technological innovation and technological transformation. Enterprises can obtain economic benefits by selling the quota, and thus guide and encourage enterprises to further carry out more emission reduction and technological improvement projects. On the other hand, the product quality brought by the enterprise's technological innovation will also increase the profit of the enterprise (Zhang et al., 2021) and offset the cost caused by reducing carbon emission. Therefore, under the implementation of carbon emission trading policy, enterprises will increase investment in technology research for long-term development, especially in the development of green and clean technologies to improve carbon emission efficiency, so as to improve the overall technical level of the city.

Secondly, carbon emission trading policy can force enterprises to optimize the energy consumption structure, thus improving the carbon emission efficiency. Energy is an important production input factor. Traditional fossil energy such as coal and oil are the main sources of sulfur dioxide and carbon dioxide emissions. On the one hand, carbon trading internalizes the cost of carbon emissions into a hidden energy price through the carbon price. Even if the energy price in the energy market remains unchanged, the change of carbon price will make the actual energy price faced by enterprises fluctuate. Therefore, in the case of carbon trading, the energy consumption mix decisions made by enterprises based on the principle of profit maximization or cost minimization is different from that without carbon trading. In this new energy consumption mix, enterprises will be more inclined to use clean and low-carbon energy, thus promoting the transformation of the energy consumption structure of the whole industry and the region to green and low-carbon direction, and promoting the transformation and upgrading of the energy consumption structure. On the other hand, with a fixed carbon emission quota, enterprises will gradually get rid of the dependence on traditional non-clean energy (Xuan et al., 2020). Increasing the investment proportion of renewable energy and other clean energy in the production process can reduce carbon emissions by reducing carbon consumption. At the same time, enterprises with slower energy consumption structure transformation will be eliminated, so as to optimize the regional energy structure and improve the carbon emission efficiency. Based on this, this paper proposes the second theoretical hypothesis:

Hypothesis 2. Carbon emission trading policy mainly improves carbon efficiency by improving technological progress, promoting green innovation and optimizing energy consumption structure.

\section{Heterogeneity Effect of Carbon Emissions Trading Policy on Carbon Emission Performance}

There is resource endowment heterogeneity in the improvement effect of carbon emission trading policy on carbon emission efficiency. On the one hand, existing studies have shown that there exists a "resource curse" phenomenon between natural resource endowment and sustainable urban development (Zhou and Fang, 2019). The development of a country or city with abundant natural resources tend to over-dependent on resource-intensive industries with low technology add-ons for a long time. With the aggravation of urban environmental pollution, it is also difficult for cities to get rid of the production mode based on traditional non-clean energy, which inhibits the improvement of technological progress and energy efficiency, and makes cities fall into the dilemma of "resource curse". However, on the other hand, cities with higher resource endowments have more advantages in industrialization. Therefore, under the constraints of environmental regulation policies, resource-based cities can make use of their own industrial development advantages to achieve technological progress and generate higher energy utilization efficiency (Shi and Li, 2020). The carbon trading policy imposes carbon emission constraints on the pilot enterprises. Under the constraints of limited carbon emission quota, the pressure of carbon emission reduction in resource-based cities increases. In order to seek a longterm mechanism for sustainable development, the incumbent enterprises need to carry out independent innovation and transform to cleaner production mode. New entrants also need to have a high level of cleaner production technology and higher carbon emission efficiency to cope with the fierce market competition. Non-resource-based cities have a high cost of using resources and mainly rely on capital-intensive or technology-intensive industries. Even in the face of limited carbon emission quota, they can use the existing production technology and production mode to achieve the emission 


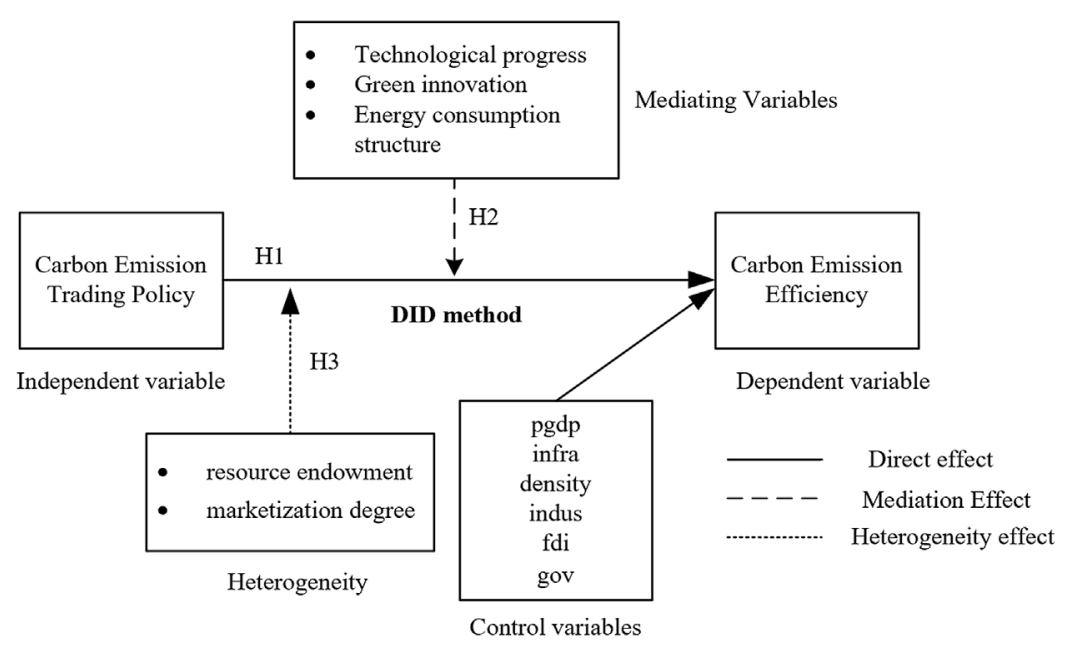

FIGURE 1 | The practical and theoretical framework.

reduction target, and the improvement of carbon emission efficiency is not obvious. Therefore, this paper speculated that carbon emission trading policy mainly affects the carbon emission efficiency of resource-based cities.

On the other hand, the effective implementation of carbon emission trading policy largely depends on the pilot cities with a high level of marketization (Wang et al., 2021). In the cities with a low level of marketization, the carbon emission trading policy will be greatly restricted and unable to internalize the emission cost (Hou et al., 2019). Besides, the governments of these cities play a more dominant role in resource allocation, which may lead to rentseeking, corruption and other phenomena. It may also cause some enterprises to purchase and store carbon emission permits far beyond their own quotas to seek monopoly benefits (Shi and Li, 2020), which leads to vicious competition in the market and is not conducive to the effective allocation of resources. While in perfect competition market, enterprises with higher carbon emission efficiency can make additional revenues. Market forces can effectively stimulate enterprises to raise the carbon efficiency, achieve energy conservation and emissions reduction (Zhou and Zhao, 2021). Therefore, we speculate that the actual effect of carbon emission trading policy is subject to the level of urban marketization. Based on the above analysis, the third hypothesis is proposed:

Hypothesis 3. There is urban heterogeneity in the effect of carbon emission trading policy on the improvement of carbon emission efficiency.

Hypothesis 3-a. : Carbon emission trading policy has a more obvious effect on the cities with higher resource endowment.

Hypothesis 3-b. : Carbon emission trading policy has a more obvious effect on the cities with higher marketization degree.

Figure 1 shows the practical and theoretical framework of this study.

\section{METHODOLOGY AND DATA}

\section{Econometric Model}

The Difference in Difference (DID) method is a commonly used method for evaluating policy effects. By comparing the impact of policies on the treatment group and the control group, the causal relationship between variables that reflect the actual effects of the policy is identified. We take Chinese carbon emission trading pilot policy as a quasi-natural experiment, taking Beijing, Shanghai, Tianjin, Chongqing, Hubei, Guangdong (including Shenzhen) and their prefecture-level cities as the processing group, other cities as the control group, and 2014 as the year of policy implementation, employing the DID to estimate the effect of the carbon emission trading system on the city's carbon emission efficiency. Based on the research of Shi and Li (2020), Wang and Lu (2019), the following model was designed:

$$
\begin{aligned}
c p_{i t}= & \alpha_{0}+\alpha_{1}\left(\text { treat }_{i t} \times \text { post }_{i t}\right)+\beta \text { control }_{i t}+\rho_{t}+\mu_{i}+\text { province }_{j} \\
& \times \text { year }_{t}+\varepsilon_{i t}
\end{aligned}
$$

Where $t, i$, and $j$ represent the year, prefecture-level city and province, respectively; $c p_{i t}$ is the dependent variable, which denotes carbon emission efficiency; treat ${ }_{i t}$ is the city dummy. treat $_{i t}=1$ when $i$ belongs to the treatment group. And treat $_{i t}=$ 0 otherwise. post it is time dummy variable. When $2014 \leq t \leq 2017$, post $i t=1$, and post $t_{i t}=0$ otherwise. control $_{i t}$ is the control variables that affects the carbon emission efficiency of a city. $\rho_{t}$ is the time fixed effect and $\mu_{i}$ is the city fixed effect that does not change with time. province $_{j} \times$ year $_{t}$ is the individual time effect of the province, which mainly controls the influence of unobservable factors changing over time of each city on the estimation results. $\varepsilon_{i t}$ is the random interference term. This model fixes the city effect, time effect and province effect, and estimates the specific impact of the carbon emission trading policy on the carbon emission efficiency of the prefecture-level cities by observing the coefficient $\alpha_{1}$. 
We use the mediation effect model (Baron and Kenny, 1986) to examine the mediation impact of the carbon emission trading policy on carbon emission efficiency, which is based on the following models:

$$
\begin{aligned}
M_{i t}= & \delta_{0}+\delta_{1}\left(\text { treat }_{i t} \times \text { post }_{i t}\right)+\text { pcontrol }_{i t}+\rho_{t}+\mu_{i}+\text { province }_{j} \\
& \times \text { year }_{t}+\varepsilon_{i t} \\
c p_{i t}= & \tau_{0}+\tau_{1}\left(\text { treat }_{i t} \times \text { post }_{i t}\right)+\theta M_{i t}+\text { qcontrol }_{i t}+\rho_{t}+\mu_{i} \\
& + \text { province }_{j} \times \text { year }_{t}+\varepsilon_{i t}
\end{aligned}
$$

Where $M_{i t}$ represents the mediating variables, including the total factor productivity, green innovation and energy consumption structure of the prefecture-level cities. The significance of the $\alpha_{1}$ in Eq. 1 is used to test whether the carbon emissions trading policy has a significant impact on the carbon emission efficiency. Eq. 2 is used to test the effect of the carbon emission trading scheme on the mediating variables. And then mediating variables and carbon emission trading both incorporated into Eq. 3. Combining these three equations, we can determine whether the intermediary effect exists. If $\theta$ is still significant, and $\tau_{1}$ is not significant or significant but lower than $\alpha_{1}$, the intermediary mechanisms of carbon emission trading system on carbon emission efficiency is improved.

\section{Variables \\ Dependent Variable}

The dependent variable in this article is the carbon emission efficiency $(c p)$ of each prefecture-level city. Some researches use total carbon emission and the ratio of carbon emission to GDP to measure carbon emission efficiency (Zhou et al., 2019; Huang and Chen, 2020). But these indicators only consider the relationship between the input of one kind of production factor and economic output, ignoring the input of capital and labor, which may lead to the one-sided estimates of carbon emission efficiency. Therefore, we mainly refer to the method of Lin and Zhou (2021) to calculate carbon emission efficiency. To be specific, we take capital (K), labor (L) and energy (E) as input variables, actual GDP (Y) as expected output, $\mathrm{CO}_{2}$ emissions $(\mathrm{C})$ as undesired output, and then apply the non-radial distance function (NDDF) and the global DEA model to calculate the carbon emission efficiency by using the overall sample construction technology Frontier.

Capital is calculated by the perpetual inventory method (Liu et al., 2017), and the labor is represented by the number of employees at the end of the year. Due to the lack of energy consumption data of prefecture-level cities, we used the method of Stein and Li Shaolin (2020) to decompose the total energy consumption of each province by using urban night light data to obtain the energy consumption of each prefecture-level city. Using the methods of existing researches (Han and Xie, 2017; Cheng et al., 2019), we calculate $\mathrm{CO}_{2}$ emission by extracting the consumption of natural gas, liquefied petroleum gas and coal power generation in each city. The main calculation formula for $\mathrm{CO}_{2}$ emission is as Eq. 4:

$$
C_{i t}=\kappa_{g} E_{g i t}+\kappa_{l} E_{l i t}+\kappa_{e}\left(\sigma_{t} \times E_{\text {eit }}\right)
$$

Among them, $E$ represents the consumption of various types of energy. $\sigma$ represents the average proportion of coal power generation to the total power generation. And $\kappa_{g}, \kappa_{l}$, and $\kappa_{e}$ represent the $\mathrm{CO}_{2}$ emission coefficients of natural gas, liquefied petroleum gas and coal power, respectively, $\left(2.1622 \mathrm{~kg} / \mathrm{m}^{3}\right.$, $3.1013 \mathrm{~kg} / \mathrm{kg}, 1.3023 \mathrm{~kg} / \mathrm{kWh}$ ) (Han and Xie, 2017).

According to Zhou et al. (2012), Lin and Zhou (2021), the non-radial distance function (NDDF) is defined as follows:

$$
\begin{gathered}
\vec{D}(K, L, E, Y, C ; \vartheta)=\sup _{\chi \geq 0}\left\{\omega^{T} \chi:(K, L, E, Y, C)+\operatorname{diag}(\chi)\right. \\
\cdot \xi \in F\}
\end{gathered}
$$

Where $\omega^{T}$ represents the weight vector of the input and output. $\xi$ represents the direction vector, and $\chi$ represents the scale factor vector of the deviation between the actual production activity and the optimal production state. $F$ represents the production framework of input and output. According to Lin and Zhou (2021), it is assumed that input, expected output, and undesired output are equally important, and the weights are all set to $1 / 3$. Therefore, the weights of labor, capital, and energy input are all $1 /$ 9, and $\mathrm{CO}_{2}$ emission efficiency (cp) is expressed as follow.

$$
c p=\frac{1 / 4\left[\left(1-\chi_{K}^{*}\right)+\left(1-\chi_{L}^{*}\right)+\left(1-\chi_{E}^{*}\right)+\left(1-\chi_{C}^{*}\right)\right]}{1+\chi_{Y}^{*}}
$$

Where $\chi^{*}=\left(\chi_{K}^{*}, \chi_{L}^{*}, \chi_{E}^{*}, \chi_{C}^{*}, \chi_{Y}^{*}\right)^{T}$ is the solution to Eq. 5. And the value of $\mathrm{cp}$ is between 0 and 1 , the larger the value, the higher the carbon emission efficiency. We preliminarily calculate the average level of carbon emission efficiency of Chinese cities. As shown in Figure 2 in Data, the average level of carbon emission efficiency of Chinese cities fluctuated from 2007 to 2017, but with small range.

\section{Control Variables}

We also include control variables that have been used in prior studies (e.g., Du et al., 2021; Xie et al., 2021).

The level of economic development $(p g d p)$. On the one hand, economic development increases carbon emissions. The extensive economic development mode will intensify the dependence on traditional non-clean energy, which is not conducive to the improvement of carbon emission efficiency (Al-Mulali et al., 2015). On the other hand, economic development promotes environment-friendly technological progress (Rajpurohit and Sharma, 2021), thus improving carbon emission efficiency (Webber and Allen, 2010). Therefore, the relationship between economic growth and carbon emissions largely determines the realization of China's transition to a green and low-carbon development mode. We use GDP per capita of the prefecture-level city to measure the level of economic development.

Infrastructure level (infra). Infrastructure construction is accompanied by a large amount of energy consumption, but the improvement of infrastructure may also improve carbon emission efficiency through the flow of factors between regions. We use the road area per capita to characterize the infrastructure level (Cheng et al., 2019). 


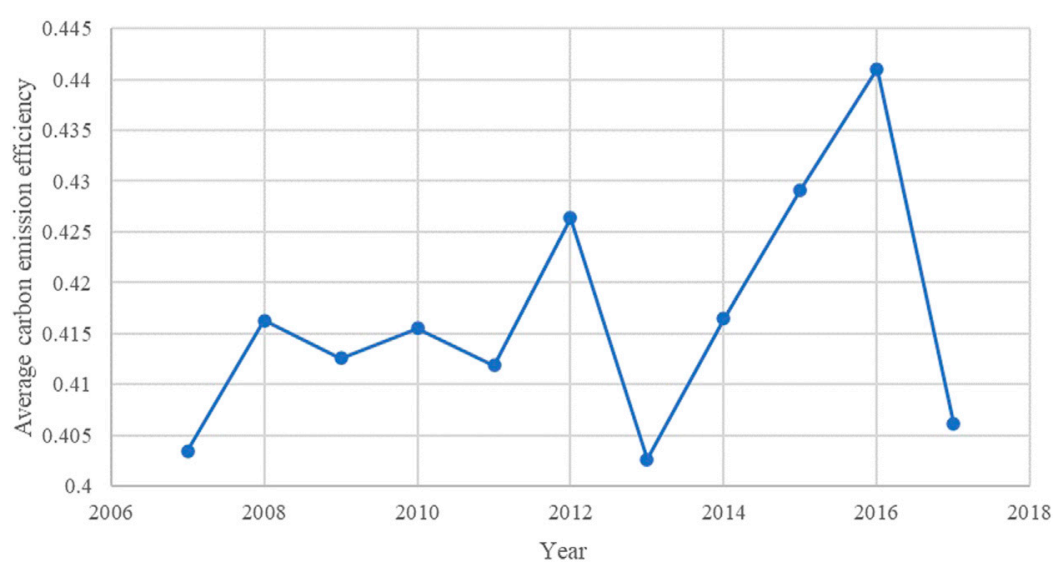

FIGURE 2 | Average level of carbon emission efficiency of Chinese cities from 2007 to 2017.

Population density (density). Population growth may generate a demographic dividend while bringing about energy consumption and carbon emissions. In addition, the increase in population density can generate a density economy through agglomeration effects, reducing clean energy production costs, and improving carbon emission efficiency (Chen et al., 2020a). We employ the population per unit of land in each administrative region to measure population density.

Industrial structure (indus). Different industrial structures have different effects on carbon efficiency. It is generally believed that the secondary industry consumes more energy and emits more pollution ( $\mathrm{Xu}$ and Lin, 2015), and accompanied by a large amount of carbon emissions (Sarwar and Alsaggaf, 2021). The share of value-added of secondary industry in GDP is used to measure the industrial structure of each city.

Foreign direct investment $(f d i)$. On the one hand, foreign direct investment can bring advanced production technology and institutional environment, and promote local carbon emission efficiency. On the other hand, based on the hypothesis of "pollution havens", foreign direct investment may cause local cities to undertake a large number of polluting enterprises, which is not conducive to the improvement of local carbon emission efficiency (Cole et al., 2010). In this paper, the proportion of foreign direct investment in GDP is used as an indicator of foreign direct investment.

Government intervention (gov). Excessive government intervention may reduce the dominant position of the market, which is not conducive to the effective allocation of resources and the reduction of carbon emission efficiency (Shao and Yang, 2014). We use the ratio of fiscal expenditure to GDP to measure the degree of government intervention.

\section{Mediating Variables}

Technological progress $(t f p)$. The city's total factor productivity is used as the indicator of technological progress. We use capital, labor, and energy as input variables, real GDP as the output variable, employing the DEA-Malmquist index to calculate the total factor productivity growth of each city.
Green innovation (gpat). According to Xu et al. (2021), due to the lag in patent grant, it is impossible to effectively measure the current level of green innovation efforts and green innovation levels in various regions. Therefore, this paper uses green patent application data of each prefecture-level city to characterize the green innovation.

Energy consumption structure (cestru). Replacing traditional fossil energy with renewable clean energy is the main way to optimize energy consumption structure. However, there is no clean energy consumption data reported at the city level. Therefore, using the method of Xu et al. (2021) as reference, the proportion of electricity consumption in total energy consumption is used to measure energy consumption structure. Since the carbon emission produced by coal power is the highest among all power generation fuels, this paper uses the proportion of coal power consumption to measure the energy consumption structure.

The detailed description and measurements of all the variables used in this study are provided in Table $\mathbf{1}$.

\section{Data}

After data preprocessing and limited to data availability, we finally obtained the research samples of 282 prefecture-level cities in China from 2007 to 2017, excluding Tibet, Hong Kong, Macao and Taiwan. The data of the dependent variables and the control variables are from the "China City Statistical Yearbook", "China Statistical Yearbook", "China Energy Statistical Yearbook", and "China Electric Power Statistical Yearbook". The green patent application data comes from the CNRDS database, and the city night light data comes from Harvard Dataverse. The missing data is supplemented by interpolation. All control variables are logarithmically processed to eliminate heteroscedasticity, and the variables with larger standard deviations are winsorized. The descriptive statistics of the original data are shown in Table 2. It can be seen that the carbon emission efficiency of the experimental group is $10.3 \%$ higher than that of the treatment group on average, which preliminarily shows that the carbon emission trading pilot has a positive impact on carbon emission efficiency. 
TABLE 1 | Variable definitions.

\begin{tabular}{|c|c|c|c|}
\hline Description & Variable & Category & Measurements \\
\hline city dummyvariable & treat $_{i t}$ & $\begin{array}{l}\text { Independent } \\
\text { variable }\end{array}$ & treat $_{\text {it }}=1$ when $i$ belongs to the treatment group; otherwise, treat $t_{\text {it }}=0$ \\
\hline time dummy variable & post $_{i t}$ & & when $2014 \leq t \leq 2017$, post $_{i t}=1$, otherwise, post $t_{i t}=0$ \\
\hline Carbon emission efficiency & $c p$ & Dependent variable & $\begin{array}{l}\text { We mainly refer to the method of Lin and Zhou (2021), taking capital }(\mathrm{K}) \text {, labor }(\mathrm{L}) \text { and energy }(\mathrm{E}) \text { as input } \\
\text { variables, actual GDP }(\mathrm{Y}) \text { as expected output, CO2 emissions }(\mathrm{C}) \text { as undesired output, and applying the } \\
\text { non-radial distance function (NDDF), adopting the global DEA model to calculate }\end{array}$ \\
\hline $\begin{array}{l}\text { The level of economic } \\
\text { development }\end{array}$ & $p g d p$ & & GDP per capita \\
\hline Infrastructure level & infra & Control Variables & Road area per capita \\
\hline Population density & density & & Population per unit of land \\
\hline Industrial structure & indus & & The share of value-added of secondary industry in GDP \\
\hline Foreign direct investment & fdi & & The proportion of foreign direct investment in GDP \\
\hline Government intervention & gov & & The ratio of fiscal expenditure to GDP \\
\hline Technological progress & $t f p$ & & Total factor productivity \\
\hline Green innovation & gpat & Mediating Variables & Number of patent applications \\
\hline Energy consumption structure & cestru & & The proportion of electricity consumption in total energy consumption \\
\hline
\end{tabular}

TABLE 2 | Descriptive statistics of variables.

\begin{tabular}{|c|c|c|c|c|c|c|c|c|c|}
\hline \multirow[b]{2}{*}{ Variable } & \multicolumn{3}{|c|}{ The full sample } & \multicolumn{3}{|c|}{ The treatment group } & \multicolumn{3}{|c|}{ The control group } \\
\hline & Obs. & Mean & Std.Dev. & Obs. & Mean & Std.Dev. & Obs. & Mean & Std.Dev. \\
\hline$c p$ & 3,102 & 0.417 & 0.148 & 407 & 0.506 & 0.183 & 2,695 & 0.403 & 0.137 \\
\hline$p g d p$ & 3,102 & 33,433 & 31,852 & 407 & 52,161 & 54,800 & 2,695 & 30,604 & 25,578 \\
\hline infra & 3,102 & 11.737 & 8.466 & 407 & 12.796 & 11.483 & 2,695 & 11.577 & 7.901 \\
\hline density & 3,102 & 456 & 654.962 & 407 & 770 & $1,295.876$ & 2,695 & 408 & 472.723 \\
\hline indus & 3,102 & 0.489 & 0.108 & 407 & 0.473 & 0.086 & 2,695 & 0.492 & 0.110 \\
\hline$f d i$ & 3,102 & 0.032 & 0.120 & 407 & 0.034 & 0.077 & 2,695 & 0.032 & 0.126 \\
\hline gov & 3,102 & 0.084 & 0.071 & 407 & 0.090 & 0.054 & 2,695 & 0.083 & 0.073 \\
\hline$t f p$ & 2,820 & 1.014 & 0.125 & 370 & 1.012 & 0.119 & 2,450 & 1.014 & 0.125 \\
\hline gpat & 3,102 & 195.277 & 544.593 & 407 & 485.103 & 991.663 & 2,695 & 151.508 & 422.586 \\
\hline cestru & 3,102 & 0.072 & 0.061 & 407 & 0.098 & 0.053 & 2,695 & 0.068 & 0.061 \\
\hline
\end{tabular}

\section{RESULTS AND DISCUSSION}

\section{Baseline Estimation Results}

In this section, we use the DID method to estimate Eq. 1, and the results are shown in Table 3. Column (1) is the estimated result of the relationship between the carbon emission trading pilot policy and carbon emission efficiency, and column (2) shows the average treatment effect of China's carbon emission trading pilot on carbon emission efficiency after the introduction of control variables based on the benchmark regression analysis. We introduce the time trend after the policy implementation year in column (3), showing the dynamic effect of carbon emission trading policy. Column (4), on the basis of column (3), further introduces the time trend for the first three years before policy implementation to test whether the carbon emissions trading policy meets the parallel trend assumption of the DID model. current represents the intersection of treat and the dummy variable in 2014, which is defined as the base year. pre_3 is the intersection of treat and the dummy variable in the third year before the implementation of the policy, that is, the year of 2011. And post_1 is the intersection of treat and the dummy variable in the first year after the implementation of the policy, that is, the year of 2015, and so on. All regressions control the city effect, time effect, and province effect.

It can be seen from Table 3 that after adding the control variables, the estimated coefficient of treat $*$ post is still positive at the significance level of $1 \%$, which indicates that China's carbon emission trading pilot has a promoting effect on carbon emission efficiency of the prefecture-level city and can effectively promote the achievement of green economy transformation. By observing the dynamic effects of the policy, during the implementation period, the carbon emission efficiency was only increased by 0.0728 . As time went on, the carbon emission efficiency increased by 0.1579 and 0.1464 at $1 \%$ significance level in the second and third years after the policy was implemented, which indicate that the effect of carbon emissions trading policies has been increasing year by year. According to column (4) and the dynamic effect diagram of parallel trend test in Figure 3, it can be seen that before the implementation of the policy, the time trend coefficients are not significant, and the coefficient value is around 0 . After the implementation of the policy, the coefficient rises rapidly, and has conversed from the negative coefficient before the pilot to the positive coefficient, which satisfies the assumption of parallel trends and indicates that 
TABLE 3 | The baseline results.

\begin{tabular}{|c|c|c|c|c|}
\hline & \multicolumn{4}{|c|}{ Dependent variable: $\mathbf{c p}$} \\
\hline & (1) & (2) & (3) & (4) \\
\hline treat ${ }^{*}$ post & $\begin{array}{c}0.0622^{* * * * *} \\
(0.0000)\end{array}$ & $\begin{array}{c}0.0452^{* * *} \\
(0.0101)\end{array}$ & & \\
\hline pre_3 & & & & $\begin{array}{l}-0.0081 \\
(0.0131)\end{array}$ \\
\hline pre_2 & & & & $\begin{array}{c}0.0004 \\
(0.0142)\end{array}$ \\
\hline pre_1 & & & & $\begin{array}{l}-0.0002 \\
(0.0143)\end{array}$ \\
\hline current & & & $\begin{array}{c}0.0728^{* * * *} \\
(0.0123)\end{array}$ & $\begin{array}{c}0.0359 \\
(0.0264)\end{array}$ \\
\hline post_1 & & & $\begin{array}{c}0.1119^{* * * *} \\
(0.0141)\end{array}$ & $\begin{array}{l}0.0384^{*} \\
(0.0209)\end{array}$ \\
\hline post_2 & & & $\begin{array}{c}0.1579^{* * *} \\
(0.0144)\end{array}$ & $\begin{array}{c}0.0222 \\
(0.0251)\end{array}$ \\
\hline post_3 & & & $\begin{array}{c}0.1464^{* * * *} \\
(0.0139)\end{array}$ & $\begin{array}{c}0.1010^{* * * *} \\
(0.0257)\end{array}$ \\
\hline Inpgdp & & $\begin{array}{c}0.0773^{* *} \\
(0.0284)\end{array}$ & $\begin{array}{c}0.0773^{* *} \\
(0.0284)\end{array}$ & $\begin{array}{l}0.0773^{* *} \\
(0.0284)\end{array}$ \\
\hline Ininfra & & $\begin{array}{l}-0.0058 \\
(0.0086)\end{array}$ & $\begin{array}{l}-0.0058 \\
(0.0086)\end{array}$ & $\begin{array}{l}-0.0058 \\
(0.0086)\end{array}$ \\
\hline Indensity & & $\begin{array}{l}0.0715^{* *} \\
(0.0346)\end{array}$ & $\begin{array}{l}0.0715^{* *} \\
(0.0346)\end{array}$ & $\begin{array}{l}0.0715^{* *} \\
(0.0346)\end{array}$ \\
\hline Inindus & & $\begin{array}{c}-0.1028^{* *} \\
(0.0409)\end{array}$ & $\begin{array}{c}-0.1028^{* *} \\
(0.0409)\end{array}$ & $\begin{array}{r}-0.1028^{*} \\
(0.0409)\end{array}$ \\
\hline Infdi & & $\begin{array}{l}-0.0005 \\
(0.0013)\end{array}$ & $\begin{array}{l}-0.0005 \\
(0.0013)\end{array}$ & $\begin{array}{l}-0.0005 \\
(0.0013)\end{array}$ \\
\hline Ingov & & $\begin{array}{c}-0.0261^{* * *} \\
(0.0113)\end{array}$ & $\begin{array}{c}-0.0261^{* *} \\
(0.0113)\end{array}$ & $\begin{array}{r}-0.0261 \text { * } \\
(0.0113)\end{array}$ \\
\hline cons & $\begin{array}{c}0.3858^{* * * *} \\
(0.0000)\end{array}$ & $\begin{array}{c}-0.9059^{*} \\
(0.4781)\end{array}$ & $\begin{array}{c}-0.8788^{*} \\
(0.4762)\end{array}$ & $\begin{array}{c}-0.9034^{*} \\
(0.4736)\end{array}$ \\
\hline City effect & YES & YES & YES & YES \\
\hline Time effect & YES & YES & YES & YES \\
\hline Province effect & YES & YES & YES & YES \\
\hline $\begin{array}{l}\mathrm{N} \\
R^{2}\end{array}$ & $\begin{array}{l}3102 \\
0.160\end{array}$ & 3102 & 3102 & $\begin{array}{l}3102 \\
0.195\end{array}$ \\
\hline
\end{tabular}

Note: the values in brackets are standard errors; ****, **, and * indicate significance at the 1,5 , and $10 \%$ levels, respectively.

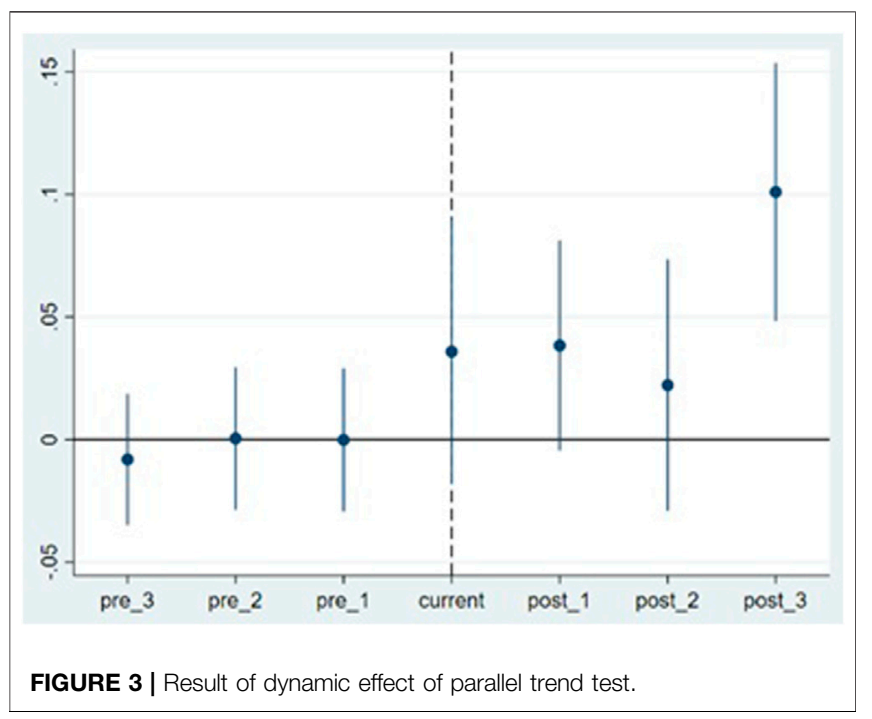

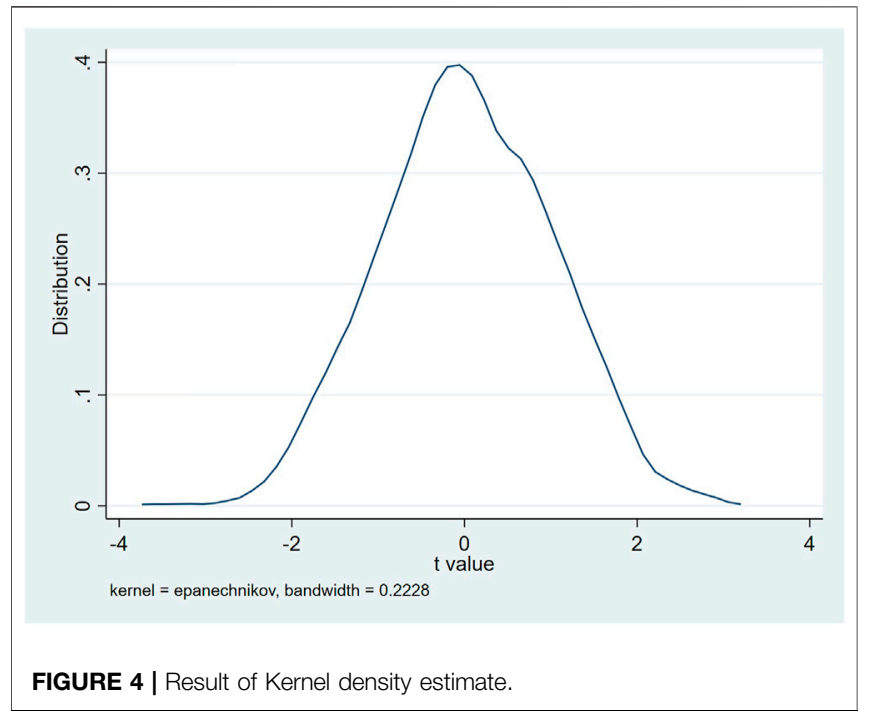

there is no significant difference between pilot cities and nonpilot cities before 2014. Therefore, the promotion effect of the carbon emission trading system on the carbon emission efficiency is proved. That is, Hypothesis 1 is confirmed. In addition, by observing the coefficients of the control variables, it is found that economic development and population density increase significantly promote carbon emission performance. The increase in the proportion of the secondary industry in the economy and excessive government intervention are not conducive to the improvement of carbon emission efficiency.

\section{Robustness Check Results Placebo Test}

In the process of estimating the impact of carbon emission trading policy on carbon emission efficiency, other unknown factors may affect the selection of pilot cities. To ensure the robustness of the conclusions obtained in this paper, placebo tests are required. Specifically referring to the method of Stein and Li Shaolin (2020), we sampled 1,000 times in 282 cities, randomly selected 37 virtual experimental groups, and took other cities as the control group for re-regression. The kernel density distribution of the dependent variable is shown in Figure 4. It can be seen that the absolute value of $\mathrm{t}$-values of most sampling estimation coefficients is less than 2 , and the $p$-values are mostly above 0.1 , indicating that the carbon emission trading system has no significant effect in 1,000 random samplings, which shows that the promotion effect is caused by the exogenous impact of the carbon emission trading policy, and has little to do with other factors.

\section{Dynamic Time Window Inspection}

Learning from the practice of Shi and Li,. (2020), we change the regression time interval to identify the difference in carbon emission efficiency in different time periods. Specifically, we take 2014 as the middle point, and selecting 1, 2 and 3 years before and after the year of 2014 to perform the regression respectively, and the results are shown in column (1)-column 
TABLE 4 | The results of robustness test

\begin{tabular}{|c|c|c|c|c|c|c|}
\hline & \multicolumn{3}{|c|}{ Dynamic time window inspection } & \multicolumn{2}{|c|}{ Counterfactual test } & \multirow{2}{*}{$\frac{\text { PSM-DID }}{(6)}$} \\
\hline & (1) & (2) & (3) & (4) & (5) & \\
\hline & 1 year & 2 years & 3 years & 2012 & 2013 & PSM-DID \\
\hline treat*post & $\begin{array}{l}0.1087^{\star \star} \\
(0.0446)\end{array}$ & $\begin{array}{c}0.0578^{\star} \\
(0.0309)\end{array}$ & $\begin{array}{c}0.0738^{\star \star \star} \\
(0.0084)\end{array}$ & & & $\begin{array}{c}0.0758^{\star \star \star} \\
(0.0148)\end{array}$ \\
\hline treat*post2012 & & & & $\begin{array}{c}0.0052 \\
(0.0055)\end{array}$ & & \\
\hline treat*post2013 & & & & & $\begin{array}{c}0.0416 \\
(0.0309)\end{array}$ & \\
\hline Inpgdp & $\begin{array}{l}0.4695^{\star \star} \\
(0.2215)\end{array}$ & $\begin{array}{c}0.2700 \\
(0.1886)\end{array}$ & $\begin{array}{c}0.0268 \\
(0.0234)\end{array}$ & $\begin{array}{l}-0.0293 \\
(0.0232)\end{array}$ & $\begin{array}{l}0.4559^{\star} \\
(0.2663)\end{array}$ & $\begin{array}{l}0.0709^{\star *} \\
(0.0268)\end{array}$ \\
\hline Ininfra & $\begin{array}{l}-0.0120 \\
(0.0089)\end{array}$ & $\begin{array}{l}-0.0060 \\
(0.0070)\end{array}$ & $\begin{array}{l}-0.0041 \\
(0.0068)\end{array}$ & $\begin{array}{l}0.0219^{\star \star \star} \\
(0.0076)\end{array}$ & $\begin{array}{l}0.0112^{*} \\
(0.0061)\end{array}$ & $\begin{array}{l}-0.0049 \\
(0.0088)\end{array}$ \\
\hline Indensity & $\begin{array}{c}0.0299 \\
(0.0209)\end{array}$ & $\begin{array}{c}0.0148 \\
(0.0176)\end{array}$ & $\begin{array}{l}0.0281^{*} \\
(0.0152)\end{array}$ & $\begin{array}{l}-0.0287 \\
(0.0184)\end{array}$ & $\begin{array}{c}0.0152 \\
(0.0163)\end{array}$ & $\begin{array}{l}0.06499^{\star *} \\
(0.0309)\end{array}$ \\
\hline Inindus & $\begin{array}{l}-0.1161 \\
(0.0746)\end{array}$ & $\begin{array}{l}-0.1234 \\
(0.0947)\end{array}$ & $\begin{array}{c}-0.0637^{\star} \\
(0.0351)\end{array}$ & $\begin{array}{l}-0.0532 \\
(0.0924)\end{array}$ & $\begin{array}{l}-0.2166 \\
(0.1430)\end{array}$ & $\begin{array}{c}-0.0989^{\star *} \\
(0.0408)\end{array}$ \\
\hline Infdi & $\begin{array}{c}0.0012 \\
(0.0031)\end{array}$ & $\begin{array}{c}0.0036 \\
(0.0025)\end{array}$ & $\begin{array}{c}0.0001 \\
(0.0020)\end{array}$ & $\begin{array}{r}-0.0015 \\
(0.0026)\end{array}$ & $\begin{array}{l}0.0077^{\star \star} \\
(0.0036)\end{array}$ & $\begin{array}{l}-0.0007 \\
(0.0013)\end{array}$ \\
\hline Ingov & $\begin{array}{l}-0.0168 \\
(0.0099)\end{array}$ & $\begin{array}{l}-0.0193 \\
(0.0130)\end{array}$ & $\begin{array}{c}-0.0479^{\star \star \star} \\
(0.0118)\end{array}$ & $\begin{array}{l}-0.0252 \\
(0.0166)\end{array}$ & $\begin{array}{l}-0.0156 \\
(0.0155)\end{array}$ & $\begin{array}{c}-0.0246^{\star \star} \\
(0.0107)\end{array}$ \\
\hline cons & $\begin{array}{c}-4.6433^{\star} \\
(2.3561)\end{array}$ & $\begin{array}{l}-2.5005 \\
(2.0233)\end{array}$ & $\begin{array}{l}-0.1581 \\
(0.2825)\end{array}$ & $\begin{array}{l}0.7100^{\star *} \\
(0.2944)\end{array}$ & $\begin{array}{l}-4.4671 \\
(2.8223)\end{array}$ & $\begin{array}{c}-0.7722^{*} \\
(0.4308)\end{array}$ \\
\hline City effect & Yes & Yes & Yes & Yes & Yes & Yes \\
\hline Time effect & Yes & Yes & Yes & Yes & Yes & Yes \\
\hline Province effect & Yes & Yes & Yes & Yes & Yes & Yes \\
\hline $\mathrm{N}$ & 846 & 1,410 & 1974 & 846 & 846 & 3080 \\
\hline$R^{2}$ & 0.425 & 0.313 & 0.272 & 0.302 & 0.350 & 0.198 \\
\hline
\end{tabular}

Note: the values in brackets are standard errors; ***, **, and * indicate significance at the 1, 5, and 10\% levels, respectively.

(3) of Table 4. The results show that the coefficients of carbon trading policies are all significantly positive, indicating that changing the policy implementation time window does not change the direction of the carbon emission trading policy's impact on carbon emission efficiency. The previous conclusions are still supported and our conclusions are robust.

\section{Counterfactual Test}

We artificially set the time point of the pilot carbon emission trading in order to prove that if there is no carbon emission trading policy, the carbon emission efficiency of the experimental group and the control group will not change significantly over time (Hung et al., 2013; Shi and Li, 2020). We set 2012 and 2013 as the year for the implementation of carbon emission trading policy to regress, respectively, and the results are shown in column (4) and column (5) of Table 4. It is shown that the coefficients of the two key interaction terms are not significant, indicating that before 2014, the carbon emission rights trading policy has no significant impact on the carbon emission efficiency of the treatment group and the control group, which indicate that the improvement of urban carbon emission efficiency is indeed brought about by carbon emissions trading policy.

\section{PSM-DID Method}

The DID method cannot ensure that the experimental group and the control group have similar individual characteristics before policy implementation. In order to overcome the systematic differences in the changing trends between the pilot cities and other cities, we further use the PSM-DID method to conduct a robustness test. Specifically, the propensity score matching method (PSM) is used to match the cities of the treatment group and the control group with the control variable as the identification feature of the samples. We perform DID regression on the matched samples, and the result is shown in column (6) of Table 4. It can be seen that the coefficient of the carbon emission trading policy is still significantly positive, and the estimated result is not significantly different from the previous article, which further supports our conclusions, indicating that the carbon emission trading policy can effectively improve carbon emission efficiency.

\section{The Impact Mechanism of Carbon Emissions Trading Policy on Carbon Emission Performance}

According to the above analysis, China's carbon emission trading pilot can help improve the efficiency of carbon emissions in prefecture-level cities. But how can this effect be achieved? According to the theoretical analysis part, we discuss the impact mechanism of China's carbon emission trading system on carbon emission efficiency from three aspects: technological progress, green innovation and energy consumption structure. 
TABLE 5 | The results of the mediating effect.

\begin{tabular}{|c|c|c|c|c|c|c|c|}
\hline & (1) & (2) & (3) & (4) & (5) & (6) & (7) \\
\hline & cp & $t f p$ & cp & gpat & cp & cestru & $\mathrm{cp}$ \\
\hline treat*post & $\begin{array}{c}0.045^{* * * *} \\
(0.010)\end{array}$ & $\begin{array}{l}0.144^{\text {**** }} \\
(0.009)\end{array}$ & $\begin{array}{c}0.027^{\text {***** }} \\
(0.009)\end{array}$ & $\begin{array}{c}245.369^{* * *} \\
(77.643)\end{array}$ & $\begin{array}{c}0.016 \\
(0.014)\end{array}$ & $\begin{array}{c}-0.017^{* * * *} \\
(0.004)\end{array}$ & $\begin{array}{l}0.037^{* * 8} \\
(0.010)\end{array}$ \\
\hline$t f p$ & & & $\begin{array}{l}0.074^{*} \\
(0.041)\end{array}$ & & & & \\
\hline gpat & & & & & $\begin{array}{c}0.000013^{*} \\
(0.000)\end{array}$ & & \\
\hline cestru & & & & & & & $\begin{array}{c}-0.450 \text { *** } \\
(0.120)\end{array}$ \\
\hline Inpgdp & $\begin{array}{l}0.077^{* *} \\
(0.028)\end{array}$ & $\begin{array}{l}0.058^{*} \\
(0.032)\end{array}$ & $\begin{array}{l}0.066^{* * *} \\
(0.024)\end{array}$ & $\begin{array}{c}-110.583 \\
(72.763)\end{array}$ & $\begin{array}{l}0.079^{* *} \\
(0.029)\end{array}$ & $\begin{array}{l}-0.008 \\
(0.009)\end{array}$ & $\begin{array}{l}0.074^{* * 8} \\
(0.025)\end{array}$ \\
\hline Ininfra & $\begin{array}{l}-0.006 \\
(0.009)\end{array}$ & $\begin{array}{l}0.017^{*} \\
(0.009)\end{array}$ & $\begin{array}{l}-0.007 \\
(0.007)\end{array}$ & $\begin{array}{l}-42.143 \\
(37.731)\end{array}$ & $\begin{array}{l}-0.005 \\
(0.009)\end{array}$ & $\begin{array}{c}-0.008^{*} \\
(0.004)\end{array}$ & $\begin{array}{l}-0.010 \\
(0.008)\end{array}$ \\
\hline Indensity & $\begin{array}{l}0.072^{* * *} \\
(0.035)\end{array}$ & $\begin{array}{c}0.039 \\
(0.029)\end{array}$ & $\begin{array}{l}0.063^{*} \\
(0.031)\end{array}$ & $\begin{array}{c}1.216 \\
(53.073)\end{array}$ & $\begin{array}{l}0.071^{*} \\
(0.035)\end{array}$ & $\begin{array}{l}-0.006 \\
(0.009)\end{array}$ & $\begin{array}{l}0.069^{* 3} \\
(0.032)\end{array}$ \\
\hline Inindus & $\begin{array}{c}-0.103^{* * *} \\
(0.041)\end{array}$ & $\begin{array}{l}-0.006 \\
(0.070)\end{array}$ & $\begin{array}{c}-0.116^{* *} \\
(0.047)\end{array}$ & $\begin{array}{c}-384.884^{* *} \\
(174.778)\end{array}$ & $\begin{array}{c}-0.098^{* * *} \\
(0.042)\end{array}$ & $\begin{array}{l}-0.017 \\
(0.026)\end{array}$ & $\begin{array}{c}-0.110^{* * *} \\
(0.037)\end{array}$ \\
\hline Infdi & $\begin{array}{c}-0.0005 \\
(0.001)\end{array}$ & $\begin{array}{l}-0.002 \\
(0.003)\end{array}$ & $\begin{array}{l}0.0007 \\
(0.002)\end{array}$ & $\begin{array}{c}26.783^{* *} \\
(9.970)\end{array}$ & $\begin{array}{c}-0.0009 \\
(0.001)\end{array}$ & $\begin{array}{c}0.0006 \\
(0.0006)\end{array}$ & $\begin{array}{c}-0.0002 \\
(0.001)\end{array}$ \\
\hline Ingov & $\begin{array}{c}-0.026^{* *} \\
(0.011)\end{array}$ & $\begin{array}{l}-0.004 \\
(0.011)\end{array}$ & $\begin{array}{c}-0.031^{* * * *} \\
(0.011)\end{array}$ & $\begin{array}{c}-120.1^{* * * *} \\
(35.810)\end{array}$ & $\begin{array}{c}-0.025^{* * *} \\
(0.011)\end{array}$ & $\begin{array}{l}0.010^{\text {**** }} \\
(0.003)\end{array}$ & $\begin{array}{l}-0.022^{*} \\
(0.011)\end{array}$ \\
\hline cons & $\begin{array}{c}-0.906^{*} \\
(0.478)\end{array}$ & $\begin{array}{c}0.218 \\
(0.488)\end{array}$ & $\begin{array}{c}-0.832^{*} \\
(0.457)\end{array}$ & $\begin{array}{l}-296.778 \\
(907.308)\end{array}$ & $\begin{array}{c}-0.899^{*} \\
(0.484)\end{array}$ & $\begin{array}{l}0.227^{*} \\
(0.125)\end{array}$ & $\begin{array}{c}-0.804^{*} \\
(0.428)\end{array}$ \\
\hline City effect & YES & YES & YES & YES & YES & YES & YES \\
\hline Time effect & YES & YES & YES & YES & YES & YES & YES \\
\hline Province effect & YES & YES & YES & YES & YES & YES & YES \\
\hline $\mathrm{N}$ & 3102 & 2820 & 2820 & 3102 & 3102 & 3102 & 3102 \\
\hline$R^{2}$ & 0.195 & 0.307 & 0.215 & 0.443 & 0.197 & 0.416 & 0.230 \\
\hline
\end{tabular}

Note: the values in brackets are standard errors; ***, **, and * indicate significance at the 1, 5, and 10\% levels, respectively.

The results are shown in Table 5. It can be seen from column (1) that the total effect of the carbon emission trading system on the city's carbon emission efficiency is 0.0452 at $1 \%$ significance level. Columns (2), (4), and (6), respectively, give the estimation results of the carbon emission trading system on the city's total factor productivity, green patent applications, and energy consumption structure. Columns (3), (5), and (7), respectively, show the result of the mediation by incorporating the three intermediary variables and the carbon emission trading system into the regression model. From columns (2), (4), and (6), we can see that the carbon emission trading policy has positive impacts on both the city's total factor productivity and the number of green patent applications at a significance level of $1 \%$, and has a negative impact on energy consumption structure at the significance level of $1 \%$, indicating that the implementation of carbon emission trading pilots can effectively promote technological progress, achieve green innovation, reduce dependence on non-clean energy, and optimize urban energy consumption structure of prefecture-level cities. In column (3), the regression coefficient of total factor productivity on urban carbon emission efficiency is significantly positive, and the coefficient of carbon trading policy is 0.0271 , which is less than 0.0452 , indicating that carbon emission trading policies can achieve carbon emission efficiency by improving city's technological progress. The result of column (5) shows that the coefficient of green patent applications is significantly positive, and the coefficient of carbon trading pilot is positive but not significant, which indicate that the green innovation effect is a completely intermediary variable. It confirms the existence of the "Porter effect" of market-oriented environmental regulations, that is, the market-oriented environmental regulations can improve the efficiency of urban carbon emissions by promoting green innovation. The results of column (7) show that the energy consumption structure has a significant negative impact on carbon emission efficiency. The coefficient of carbon trading policy is still significantly positive but its value is less than 0.0452 , indicating that carbon emissions trading policies can produce energy structure optimization effects, and then achieve the improvement impact on the carbon emission efficiency. In summary, Hypothesis 2 is verified.

\section{HETEROGENEITY ANALYSIS}

\section{Heterogeneity of Resource Endowment}

For all cities, carbon emission rights trading policy can effectively promote the improvement of carbon emission efficiency. However, due to the large differences in the resource endowments of various cities, the economic growth patterns of Chinese cities are different, and the uneven development characteristics are prominent. Based on the overall city 
TABLE 6 | The results of heterogeneity test.

\begin{tabular}{|c|c|c|c|c|}
\hline & (1) & (2) & (3) & (4) \\
\hline & resource-based cities & non-resource-based cities & high-marketization cities & low-marketization cities \\
\hline \multirow[t]{2}{*}{ treat post } & $0.0831^{* * * * *}$ & 0.1058 & $0.0845^{* *}$ & 0.0244 \\
\hline & $(0.0196)$ & $(0.0661)$ & $(0.0375)$ & $(0.0211)$ \\
\hline \multirow[t]{2}{*}{ Inpgdp } & 0.0698 & 0.0902 & 0.0636 & $0.1444^{* * *}$ \\
\hline & $(0.0485)$ & $(0.0674)$ & $(0.0533)$ & $(0.0454)$ \\
\hline \multirow[t]{2}{*}{ Ininfra } & -0.0149 & -0.0025 & -0.0018 & -0.0072 \\
\hline & $(0.0147)$ & $(0.0097)$ & $(0.0127)$ & $(0.0077)$ \\
\hline \multirow[t]{2}{*}{ Indensity } & 0.0563 & 0.0883 & 0.0675 & $0.1164^{* * *}$ \\
\hline & $(0.0484)$ & $(0.0644)$ & $(0.0548)$ & $(0.0405)$ \\
\hline \multirow[t]{2}{*}{ Inindus } & -0.0224 & $-0.1446^{* * *}$ & 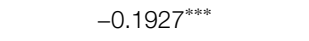 & $-0.0644^{*}$ \\
\hline & $(0.0596)$ & $(0.0568)$ & $(0.0721)$ & $(0.0354)$ \\
\hline \multirow[t]{2}{*}{ Infdi } & -0.0023 & 0.0011 & -0.0030 & 0.0001 \\
\hline & $(0.0034)$ & $(0.0026)$ & $(0.0034)$ & $(0.0021)$ \\
\hline \multirow[t]{2}{*}{ Ingov } & $-0.0295^{* * * *}$ & $-0.0308^{* * * *}$ & $-0.0342^{* * * *}$ & $-0.0201^{* *}$ \\
\hline & $(0.0094)$ & $(0.0109)$ & $(0.0115)$ & $(0.0086)$ \\
\hline \multirow[t]{2}{*}{ cons } & -0.5999 & -1.1321 & -0.7816 & $-1.6488^{* * * *}$ \\
\hline & (0.6962) & $(1.0594)$ & (0.8784) & (0.6195) \\
\hline City effect & Yes & Yes & Yes & Yes \\
\hline Time effect & Yes & Yes & Yes & Yes \\
\hline Province effect & Yes & Yes & Yes & Yes \\
\hline$N$ & 1,243 & 1859 & 1,529 & 1,573 \\
\hline$R^{2}$ & 0.375 & 0.208 & 0.151 & 0.277 \\
\hline
\end{tabular}

Note: the values in brackets are standard errors; ${ }^{* * *}, * *$, and ${ }^{*}$ indicate significance at the 1, 5, and 10\% levels, respectively.

sample, the analysis may conceal regional differences to a certain extent. Therefore, in accordance with the notice of the State on Issuing the National Sustainable Development Plan for ResourceBased Cities (2013-2020), we divide the 282 cities into resourcebased and non-resource-based cities, and examine the heterogeneous impact of carbon emission trading policy on the carbon emission efficiency by grouping the samples. The results are shown in columns (1) and (2) of Table 6. It can be seen that for resource-based cities, the coefficient of carbon emission trading policy is significantly positive at the $1 \%$ level. While for non-resource-based cities, the coefficient of carbon emissions trading policy is positive but not significant, which indicate that the improvement effect of carbon emission trading policy on the carbon emission efficiency mainly reflected in resource-based cities. The possible reason is that resource-based cities mainly focus on resource exploitation and extensive processing, and highly depends on resources. These cities mainly take traditional non-clean energy as the main input factors and is relatively poor in transformation and optimization of energy consumption structure, thus resulting in serious environmental problems. The carbon emission trading policy gives each pilot city a fixed share of carbon emission and puts forward higher requirements on the carbon emission efficiency of resourcebased cities, forcing them to carry out technological innovation, invest in cleaner production technologies, and improve the efficiency of carbon emissions in the production process to reduce carbon emissions. The cost of using energy in non-resource-based cities is relatively high. Therefore, companies have enough motivation to invest in energy-saving production technologies based on the goal of profit maximization, and their pressure on environmental protection is relatively small. Therefore, the carbon emission trading policy has a more obvious effect on improving the carbon emission efficiency of resource-based cities.

\section{Heterogeneity of Marketization Level}

The carbon emission trading policy relies on the operation of the market mechanism. By selling carbon emission rights from companies with lower carbon emissions to companies with higher carbon emissions, lower-carbon companies can obtain corresponding benefits, thereby encouraging companies to take the initiative to increase carbon emission efficiency, which in turn promotes the improvement of the carbon emission efficiency of the entire economy. If the market mechanism is not perfect, a small number of companies may purchase and store carbon emission rights that far exceed their own carbon emission quotas to obtain monopoly benefits (Shi and Li, 2020). Therefore, the effect of carbon emission rights trading policies on carbon emission efficiency will be subject to the marketization level of each city. Drawing on the practice of Shi and Li (2020), we measure the marketization level of prefecture-level cities under the jurisdiction of the total marketization index of each province in China. And refering to Zhou et al. (2019), we use the average of the marketization level before the implementation of the policy during the sample period to divide each city into two groups, high and low, and regress them respectively. The results are shown in columns (3) and (4) of Table 6. The carbon emission trading policy has a greater effect on improving the carbon emission efficiency of cities with a higher level of marketization, and the level of significance is higher, indicating that the process of city 
marketization can effectively promote the carbon emission trading policy to achieve the goal of green and low-carbon development.

\section{CONCLUSION AND POLICY IMPLICATIONS}

With the increasingly serious global environmental problems, higher requirements for carbon emission efficiency are put forward. As a major carbon emitter, China, driven by the dual carbon emission control target, urgently needs to improve carbon emission efficiency and transition to low-carbon green development. And cities should be the main players in this carbon neutral campaign. However, there are few studies on the relationship between China's carbon emission trading policy and carbon emission efficiency at the city level. Based on this, this paper uses panel data of 282 prefecture-level cities in China from 2007 to 2017 to measure urban carbon emission efficiency with the global DEA model. Taking China's carbon emission trading pilot as the quasi-natural experiment, we then study the impact of China's carbon emission trading policy on urban carbon emission efficiency based on DID model, and the main conclusions are as follows: 1) A series of robustness test studies show that China's carbon emission trading policy significantly improved the efficiency of urban carbon emissions, and the policy effect gradually increased over time; 2) The mediation effect model test results show that the carbon emission trading market can significantly improve the efficiency of urban carbon emissions by promoting technological progress, promoting green innovation and optimizing energy consumption structure; 3 ) Heterogeneity test results show that the improvement effect of China's carbon emission trading policy on carbon emission efficiency is mainly reflected in resource-based cities. And promoting the market-oriented process will help strengthen the policy effect of the carbon emission trading pilot program, which provide strong support for China to achieve green and low-carbon development through market-oriented environmental policies.

Based on the Above Research Conclusion, the Following Policy Recommendations Are Put Forward. Firstly, in the new stage of dealing with environmental pollution, we should attach great importance to the role of market-oriented environmental policies in improving urban carbon emission efficiency. Specifically, we should accelerate the construction of a national carbon trading market, improve the carbon trading mechanism, provide incentives for enterprises to improve carbon emission efficiency, so as to promote the improvement of carbon emission efficiency of the whole society.

\section{REFERENCES}

Al-Mulali, U., Saboori, B., and Ozturk, I. (2015). Investigating the Environmental Kuznets Curve Hypothesis in Vietnam. Energy Policy 76, 123-131. doi:10.1016/ j.enpol.2014.11.019

Baron, R. M., and Kenny, D. A. (1986). The Moderator-Mediator Variable Distinction in Social Psychological Research: Conceptual, Strategic, and
Secondly, the government should encourage enterprises to carry out technological innovation and establish a sound intellectual property protection system to encourage enterprises to increase their investment in green technology research and development. This is conducive to promoting the transformation of regional technological innovation to the green direction, promoting the development of new energy, helping enterprises to get rid of the dependence on traditional non-clean energy and optimizing the energy consumption structure of cities. At the same time, we should give full play to the technological progress effect, green innovation effect and energy consumption structure optimization effect of carbon emission trading policy to achieve the goal of improving carbon efficiency of cities.

Thirdly, we need to take full account of the resource endowment of cities and set up carbon trading schemes tailored to local conditions. We should also make full use of the innovation incentive effect of carbon trading policy on resource-based cities and accelerate the establishment and improvement of carbon trading mechanism in resource-based cities to make enterprises get rid of dependence on resources, thus promoting the transformation of production mode to green and clean direction.

Fourthly, we should strengthen the dominant position of the market and promote market-oriented reform. And the government departments focus on ensuring the sound operation of the free competitive market mechanism to provide sufficient liquidity for carbon emission trading scheme in the market. In turn, we can maximize the efficiency of carbon trading policy implementation and achieve green and low-carbon development of the economy.

\section{DATA AVAILABILITY STATEMENT}

The original contributions presented in the study are included in the article; further inquiries can be directed to the corresponding author.

\section{AUTHOR CONTRIBUTIONS}

Conceptualization, methodology and writing-original draft, LC and YL; Software, data curation, writing-review and editing, YG; conceptualization, methodology, writing-review and editing, supervision, JW: All authors have read and agreed to the published version of the article.

Statistical Considerations. J. Personal. Soc. Psychol. 51, 1173-1182. doi:10.1037//0022-3514.51.6.117310.1037/0022-3514.51.6.1173

Blackman, A., and Kildegaard, A. (2010). Clean Technological Change in Developing-Country Industrial Clusters: Mexican Leather Tanning. Environ. Econ. Pol. Stud. 12, 115-132. doi:10.1007/s10018-010-0164-7

Brännlund, R., Chung, Y., Färe, R., and Grosskopf, S. (1998). Emissions Trading and Profitability: The Swedish Pulp and Paper Industry. Environ. Resour. Econ. 12, 345-356. doi:10.1023/A:1008285813997 
Brouwers, R., Schoubben, F., Van Hulle, C., and Van Uytbergen, S. (2016). The Initial Impact of EU ETS Verification Events on Stock Prices. Energy Policy 94, 138-149. doi:10.1016/j.enpol.2016.04.006

Caparrós, A., Péreau, J.-C., and Tazdaït, T. (2013). Emission Trading and International Competition: The Impact of Labor Market Rigidity on Technology Adoption and Output. Energy Policy 55, 36-43. doi:10.1016/ j.enpol.2012.09.017

Chapple, L., Clarkson, P. M., and Gold, D. L. (2013). The Cost of Carbon: Capital Market Effects of the Proposed Emission Trading Scheme (ETS). Abacus 49, 1-33. doi:10.1111/abac.12006

Chen, J., Wang, B., Huang, S., and Song, M. (2020a). The Influence of Increased Population Density in China on Air Pollution. Sci. Total Environ. 735, 139456. doi:10.1016/j.scitotenv.2020.139456

Chen, S., Shi, A., and Wang, X. (2020b). Carbon Emission Curbing Effects and Influencing Mechanisms of China's Emission Trading Scheme: The Mediating Roles of Technique Effect, Composition Effect and Allocation Effect. J. Clean. Prod. 264, 121700. doi:10.1016/j.jclepro.2020.121700

Cheng, J., Yi, J., Dai, S., and Xiong, Y. (2019). Can Low-Carbon City Construction Facilitate green Growth? Evidence from China's Pilot Low-Carbon City Initiative. J. Clean. Prod. 231, 1158-1170. doi:10.1016/j.jclepro.2019.05.327

Cheng, Y., and Yao, X. (2021). Carbon Intensity Reduction Assessment of Renewable Energy Technology Innovation in China: A Panel Data Model with Cross-Section Dependence and Slope Heterogeneity. Renew. Sustain. Energ. Rev. 135, 110157. doi:10.1016/j.rser.2020.110157

Cheng, Z., Li, L., and Liu, J. (2017). The Emissions Reduction Effect and Technical Progress Effect of Environmental Regulation Policy Tools. J. Clean. Prod. 149, 191-205. doi:10.1016/j.jclepro.2017.02.105

Clarkson, P. M., Li, Y., Pinnuck, M., and Richardson, G. D. (2015). The Valuation Relevance of Greenhouse Gas Emissions under the European Union Carbon Emissions Trading Scheme. Eur. Account. Rev. 24, 551-580. doi:10.1080/ 09638180.2014.927782

Coase, R. H. (1960). The Problem of Social Cost. J. L. Econ. 3, 1-44. doi:10.1086/ 466560

Cole, M. A., Elliott, R. J. R., and Okubo, T. (2010). Trade, Environmental Regulations and Industrial Mobility: An Industry-Level Study of Japan. Ecol. Econ. 69, 1995-2002. doi:10.1016/j.ecolecon.2010.05.015

Dong, Z., and Wang, H. (2019). Local-Neighborhood" Green Technology Progress Effect of Environmental Regulation. China's Ind. Economy 100-118.

Du, K., Cheng, Y., and Yao, X. (2021). Environmental Regulation, green Technology Innovation, and Industrial Structure Upgrading: The Road to the green Transformation of Chinese Cities. Energ. Econ. 98, 105247. doi:10.1016/j.eneco.2021.105247

Han, F., and Xie, R. (2017). Has the Agglomeration of Producer Service Industries Reduced Carbon Emissions? - Spatial Measurement Analysis of Panel Data in Cities at Prefecture-Level and above in China. Quantitative Econ. Tech. Econ. Res. 34, 40-58.

Hou, B., Wang, B., Du, M., and Zhang, N. (2019). Does the SO2 Emissions Trading Scheme Encourage green Total Factor Productivity? an Empirical Assessment on China's Cities. Environ. Sci. Pollut. Res. 27 (6), 6375-6388. doi:10.1007/ s11356-019-07273-6

Huang, J., and Chen, X. (2020). Domestic R\&D Activities, Technology Absorption Ability, and Energy Intensity in China. Energy Policy 138, 111184. doi:10.1016/ j.enpol.2019.111184

Hung, M., Shi, J., and Wang, Y. (2013). The Effect of Mandatory CSR Disclosure on Information Asymmetry: Evidence from a Quasi-Natural Experiment in China. SSRN J. 33, 1-17. doi:10.2139/ssrn.2206877

Li, G., and Masui, T. (2019). Assessing the Impacts of China's Environmental Tax Using a Dynamic Computable General Equilibrium Model. J. Clean. Prod. 208, 316-324. doi:10.1016/j.jclepro.2018.10.016

Li, M., Weng, Y., and Duan, M. (2019). Emissions, Energy and Economic Impacts of Linking China's National ETS with the EU ETS. Appl. Energ. 235, 1235-1244. doi:10.1016/j.apenergy.2018.11.047

Li, Z., and Wang, J. (2021). Spatial Emission Reduction Effects of China's Carbon Emissions Trading: Quasi-Natural Experiments and Policy Spillovers. China Popul. Resour. Environ. 31 (01), 26-36. (in Chinese). doi:10.12062/ cpre.20200907
Lin, B., and Zhou, Y. (2021). Does the Internet Development Affect Energy and Carbon Emission Performance? Sustainable Prod. Consumption 28, 1-10. doi:10.1016/j.spc.2021.03.016

Liu, C., Li, L., and Wei, P. (2017). Capital Stock Measurement of Cities at Prefecture Level and above in China, Urban Probl. 67-72.

Pearse, R. (2016). The Coal Question that Emissions Trading Has Not Answered. Energy Policy 99, 319-328. doi:10.1016/j.enpol.2016.05.053

Porter, M. E., and Linde, C. v. d. (1995). Toward a New Conception of the Environment-Competitiveness Relationship. J. Econ. Perspect. 9, 97-118. doi:10.1257/jep.9.4.97

Qin, C. B., Wang, J. N., Ge, C. Z., Duan, Y. T., and Tian, C. Y. (2016). Assessing the Economic Impact of China's Carbon Tax Policy through a Static Computable General Equilibrium Analysis. in" Sustainable Development: Proceedings of the 2015 International Conference on Sustainable Development, ICSD 2015, 624-643. doi:10.1142/9789814749916_0065

Rajpurohit, S. S., and Sharma, R. (2020). Impact of Economic and Financial Development on Carbon Emissions: Evidence from Emerging Asian Economies. Meq 32 (2), 145-159. doi:10.1108/MEQ-03-2020-0043

Sarwar, S., and Alsaggaf, M. I. (2021). The Role of Governance Indicators to Minimize the Carbon Emission: a Study of Saudi Arabia. Meq 32 (5), 970-988. doi:10.1108/MEQ-11-2020-0275

Schäfer, S. (2019). Decoupling the EU ETS from Subsidized Renewables and Other Demand Side Effects: Lessons from the Impact of the EU ETS on $\mathrm{CO} 2$ Emissions in the German Electricity Sector. Energy Policy 133, 1108581-1110858. doi:10.1016/j.enpol.2019.06.066

Shakil, M. H., Mahmood, N., Tasnia, M., and Munim, Z. H. (2019). Do environmental, Social and Governance Performance Affect the Financial Performance of banks? A Cross-Country Study of Emerging Market banks. Meq 30, 1331-1344. doi:10.1108/MEQ-08-2018-0155

Shao, S., and Yang, L. (2014). Natural Resource Dependence, Human Capital Accumulation, and Economic Growth: A Combined Explanation for the Resource Curse and the Resource Blessing. Energy Policy 74, 632-642. doi:10.1016/j.enpol.2014.07.007

Shen, J., Tang, P., and Zeng, H. (2020). Does China's Carbon Emission Trading Reduce Carbon Emissions? Evidence from Listed Firms. Energ. Sustain. Dev. 59, 120-129. doi:10.1016/j.esd.2020.09.007

Shi, D., and Li, S. (2020). Emissions Trading System and Energy Use Efficiency--Measurements and Empirical Evidence for Cities at and above the Prefecture Level. China's Ind. Econ. (09), 5-23. (in Chinese). doi:10.19581/ j.cnki.ciejournal.2020.09.001

Song, D., Zhu, W., and Wang, B. (20212021). A micro-empirical study of companies covered by China's carbon trading pilots: carbon emissions trading, allowance allocation methods and corporate green innovation. China Population.Resources Environ. 31 (01), 37-47.

Song, M., Wang, S., and Zhang, H. (2020). Could environmental regulation and R\&D tax incentives affect green product innovation? J. Clean. Prod. 258, 120849. doi:10.1016/j.jclepro.2020.120849

Tang, H., Liu, J., and $\mathrm{Wu}, \mathrm{J}$. (2020). The impact of command-and-control environmental regulation on enterprise total factor productivity: A quasinatural experiment based on China's "Two Control Zone" policy. J. Clean. Prod. 254, 120011. doi:10.1016/j.jclepro.2020.120011

Tu, Z., and Chen, R. (2015). Can Emissions Trading Scheme Achieve the Poter Efficient in China? Res. 50 (07), 160-173. (in Chinese)

Wang, G., and Lu, X. (2019). The Belt and Road Initiative and the Upgrading of China's Enterprises. China Ind. Econ. (03), 43-61. (in Chinese). doi:10.19581/ j.cnki.ciejournal.2019.03.013

Wang, S., Chen, G., and Han, X. (2021). An Analysis of the Impact of the Emissions Trading System on the Green Total Factor Productivity Based on the Spatial Difference-in-Differences Approach: The Case of China. Ijerph 18 (17), 9040. doi:10.3390/ijerph18179040

Webber, D. J., and Allen, D. O. (2010). Environmental Kuznets curves: Mess or meaning? Int. J. Sustain. Dev. World Ecol. 17, 198-207. doi:10.1080/ 13504501003787638

Wu, L., and Gong, Z. (2021). Can national carbon emission trading policy effectively recover GDP losses? A new linear programming-based three-step estimation approach. J. Clean. Prod. 287, 125052. doi:10.1016/j.jclepro.2020.125052 
Xiao, J., Li, G., Zhu, B., Xie, L., Hu, Y., and Huang, J. (2021). Evaluating the impact of carbon emissions trading scheme on Chinese firms' total factor productivity. J. Clean. Prod. 306, 127104. doi:10.1016/j.jclepro.2021.127104

Xie, L., Li, Z., Ye, X., and Jiang, Y. (2021). Environmental regulation and energy investment structure: Empirical evidence from China's power industry. Technol. Forecast. Soc. Change 167, 120690. doi:10.1016/ j.techfore.2021.120690

$\mathrm{Xu}$, B., and Lin, B. (2015). How industrialization and urbanization process impacts on CO 2 emissions in China: Evidence from nonparametric additive regression models. Energ. Econ. 48, 188-202. doi:10.1016/ j.eneco.2015.01.005

Xu, L., Fan, M., Yang, L., and Shao, S. (2021). Heterogeneous green innovations and carbon emission performance: Evidence at China's city level. Energ. Econ. 99, 105269. doi:10.1016/j.eneco.2021.105269

Xuan, D., Ma, X., and Shang, Y. (2020). Can China's policy of carbon emission trading promote carbon emission reduction? J. Clean. Prod. 270, 122383. doi:10.1016/j.jclepro.2020.122383

Yang, X., Jiang, P., and Pan, Y. (2020). Does China's carbon emission trading policy have an employment double dividend and a Porter effect? Energy Policy 142, 111492. doi:10.1016/j.enpol.2020.111492

Ying, Z., and Xin-gang, Z. (2021). The impact of Renewable Portfolio Standards on carbon emission trading under the background of China's electricity marketization reform. Energy 226, 120322. doi:10.1016/ j.energy.2021.120322

Zhang, S., Wang, Y., Hao, Y., and Liu, Z. (2021). Shooting two hawks with one arrow: Could China's emission trading scheme promote green development efficiency and regional carbon equality? Energ. Econ. 101, 105412. doi:10.1016/ j.eneco.2021.105412

Zheng, D., and Shi, M. (2017). Multiple environmental policies and pollution haven hypothesis: Evidence from China's polluting industries. J. Clean. Prod. 141, 295-304. doi:10.1016/j.jclepro.2016.09.091
Zhou, D., Zhou, F., and Wang, X. (2019). Impact of Low-Carbon Pilot Policy on the Performance of Urban Carbon Emissions and its Mechanism. Resour. Sci. 41, 546-556. (in Chinese). doi:10.18402/resci.2019.03.12

Zhou, M., Li, Y., Yao, X., and Lu, Y. (2019). Human Capital Accumulation and Urban Manufacturing Export Upgrading in China: Evidence from Higher Education Expansion. Manag. World 35 (05), 64-77+198199. (in Chinese). doi:10.19744/j.cnki.11-1235/f.2019.0066

Zhou, P., Ang, B. W., and Wang, H. (2012). Energy and CO2 emission performance in electricity generation: A non-radial directional distance function approach. Eur. J. Oper. Res. 221, 625-635. doi:10.1016/j.ejor.2012.04.022

Zhou, Q., and Fang, S. (2019). Regional energy endowment, enterprise heterogeneity and energy efficiency: an empirical analysis based on micro sample data of industry-wide enterprises. Econ. Sci., 66-78. (in Chinese). doi:10.12088/PKU.jjkx.2019.02.06

Conflict of Interest: Author LC, YL, YG, and JW were employed by the company Chongqingfuling electric power industrial Co., Ltd.

Publisher's Note: All claims expressed in this article are solely those of the authors and do not necessarily represent those of their affiliated organizations, or those of the publisher, the editors, and the reviewers. Any product that may be evaluated in this article, or claim that may be made by its manufacturer, is not guaranteed or endorsed by the publisher.

Copyright (c) 2021 Chen, Liu, Gao and Wang. This is an open-access article distributed under the terms of the Creative Commons Attribution License (CC $B Y)$. The use, distribution or reproduction in other forums is permitted, provided the original author(s) and the copyright owner(s) are credited and that the original publication in this journal is cited, in accordance with accepted academic practice. No use, distribution or reproduction is permitted which does not comply with these terms. 